\title{
Design of Values Education in School For Adolescents
}

\author{
Suyatno ${ }^{1}$, Jumintono ${ }^{2}$, Dholina Inang Pambudi ${ }^{3}$, Asih Mardati ${ }^{4}$ \\ 1,2,3,4 Ahmad Dahlan University Yogyakarta \\ Yogyakarta, Indonesia \\ suyatnopgsduad@gmail.com
}

\begin{abstract}
The growth and development of values in the students themselves need to be planned, deliberate, and facilitated through education. The ongoing values education tends to ignore the uniqueness of each student. Evidently, the 18 character values developed by the Ministry of Education and Culture are top-down, thus ignoring the personal side of the students. This article attempts to answer the question of what design of values education is appropriate for students entering adolescence. This research is a literature review through library research. Data were analyzed using content analysis. Based on the study of literature, this research reveals that each student has dominant values that are specific and unique so that in its development requires an individual approach. There are two important concepts in developing values for students who are entering the adolescence phase, they are; First, the values is seen, not taught. This concept entails every adult who interact with students should be role-models for the growth of values. Second, values based on environmental education. Like plant seeds which are well developed when they get a good soil, the students' values will grow well when they have the support of values based on environmental education.
\end{abstract}

Keywords-value, adolescent, role model, and value-based environment.

\section{INTRODUCTION}

Values education is often known by different names; such as moral education, character education, and ethics education [1], Values education' is commonly understood as placing a particular emphasis on civic and moral values [12]. Values education is therefore very closely aligned to other terms currently used in the literature, including spiritual, moral, social and cultural development. Reference [2] and reference [2] refer to character education, education in virtues and the development of attitudes and personal qualities. The values education literature from the United Kingdom mostly refers to "values education, character education, moral education, personal and social education, and citizenship education" [2].

The issue of values education has become a major part of the educational policy agenda of many nations around the world [3][4][5][6][7] . Ref.[8] believed that a common thread exists among the different forms of values education.

Value education according to Winecoff H.L. \& Bufford, C. [9] is: Values education-pertains to questions of both moral and non-moral judgment toward object; includes both aesthetics (ascribing value 10 objects of beauty and personal taste) and ethics (ascribing values of right and wrong in the interpersonal realm). Winecoff reveals that the goal of values education is as follows: "Purpose of Values Education is process of helping students to explore exiting values through critical examination in order that they might improve the quality of their thinking and feeling".

In recent years, values education has become mainstreaming in the development of the formal curriculum in Indonesia. Curriculum 2006 (School-Based Curriculum) and Curriculum 2013 put the values aspect (character) as the main objective of learning activities in the classroom. However, the ongoing value education tends to ignore the uniqueness of each student. Evidently, the 18 character values promoted by the Ministry of Education and Culture are top-down, thus ignoring the personal side of each student. The neglect of the students' personal aspects will cause the values that have been grown tend to be enforced, whereas everyone has different dominant values.

This article attempts to answer the question of what design of values education is appropriate for students entering adolescence. As it is understood that adolescence are a developmental phase that has unique characters. Also the aspect of personal disposition requires that values education approach that is applied to them is also specific and flexible.

\section{NEEDS FOR VALUES OF ADOLESCENCE}

Values are 'socially shared ideas about what is good, desirable or important' [10] . Values refer to ideas held by individuals or groups concerning standards defining that is 'good or bad', what is desirable and what is not desirable [11] In short, values can be defined as "principles and fundamental convictions which act as general guides to behaviour, the standards by which particular actions are judged to be good or desirable."[12].

The students of Junior High is stated to be entering the stage of adolescence development which has different character compared to the other stage of development. There are 10 characters of adolescence development, they are: 1 . Achieving new and more mature relations with peers. 2. Bring in social roles as men or women. 3. Make use of his own body according to circumstances and utilize it effectively. 4. Have achieved emotional independence. 5. Achieving guarantees for economic independence. 6. Choosing and preparing for a particular job 7. Preparing for marriage and family life. 8. Developing intellectual skills and concepts needed as citizen competency. 9. Developing ability and willingness to act 
socially positive behavior (responsible). 10. Establishing a set of values and an ethical system as a guide to behavior [13] .

Egan [14] explains that the development of children's interest and concern for values takes place in four stages: myth, romantic, philosophical, and ironic. The four stages of development goes along with the physical growth of children who become older. The stages, in detail, can be seen in the following explaination.

\section{Stage of myth (5-10 years)}

Children learn through how to play and tell stories. They are happy to play with objects, in this case toys, that involve their feelings. At this stage moral values are the main concerns that are distinguished in black and white like good and ugly, dear and hateful, likes and dislikes.

\section{Romantic Stage ( $8-15$ years)}

In this range of age, children expect a lot of information that can provide a description of human, the spirit of life, adventure, technological developments, sports, until the problems that are foreign to them.

\section{Philosophical Stage (14-20 years)}

This stage is dominated by adolescent desire to simplify the sequence of experiences through a conclusion made by themselves or through a standard law-order. At this stage, children usually feel frustrated when there are special treatments or a conflict in law enforcement.

\section{The ironic stage (20 years and over)}

At this stage, late adolescents or adults try to find clearer conclusions based on the knowledge and experiences that they have. But drawing conclusions and explanations, including the things that are contradictory and confusing are not only appreciated but please them. At this stage late adolescents or adults are no longer frustrated by the presence of something offhanded, conflicting or contradictory.

\section{VALUES EDUCATION IN THE SCHOOLS TODAY}

Values education, or often referred to the other terms such as; character education, ethics education, moral education, etc., has always been a core in the development of curriculum enacted in schools. The 2006 curriculum known as SchoolBased Curriculum makes the character as an important aspect of measurement of learning outcomes. There are 18 character values [15] developed in school learning, which include; honesty, responsibility, healthy lifestyle, discipline, selfconfidence, hard-working, entrepreneurial spirit, logical thinking, criticality, creativity, innovation, independence, curiosity, loving sciences, consciousness of the rights and obligations of self and others, obedience of the social rules, respect of the work and achievements of others, politeness, democracy, nationalist, and appreciating the diversity.

Moreover, the 2013 curriculum is placing attitudes as the ultimate goal of learning, manifested in the form of core competencies. The spiritual and social attitudes should be used as reference in the implementation of learning. Whatever the subject, the learning process in the classroom should contribute to the achievement of spiritual and social attitudes. Learning mathematics, Indonesian, social sciences, sciences and other subjects should be able to lead the students to realize God's majesty (spiritual attitude), to make the students become honest, tolerant, wise, polite, and all other good attitudes (social attitudes).

Implementation of values education in the curriculum of 2013 is done through three strategies, namely; First, integrated in all subjects; Second, through the development of school culture; and third, through extracurricular activities. The first strategy is ensuring that all subjects in school should contribute to the development of the students' good values. The second strategy requires the culture that develops in school must be a positive culture so that it can be the cause of the growth of good values. The third strategy requires that all extracurricular activities in schools also support the growth of students' morals. Not just skill and knowledge, but extracurricular activities are also required to improve attitudes.

The concept of values education offered in the formal curriculum, both School-Based Curriculum (2006 Curriculum) and 2013 curriculum, is an ideal concept. The ideas developed are expected to improve the values/characters of the young generation in this nation. But looking at the practice that has been running in recent years, the ideal concept has not implemented properly.

\section{DISCUSSION}

\section{A. Values is Seen, Not Taught}

The important question to point out is which part is wrong in the values education in Indonesia? Is it a wrong concept or wrong implementation? Conceptually, the values education developed in the formal curriculum tends to debate on what values education is. There are substantial differences between values education and values-based education. The first concept tends to focus on discussions and debates about what values are and how to teach values. The second concept illustrates that all processes and parties involved in children's education should be values-based. Students are directly conditioned to experience values-based atmosphere and events. For example, students may have not fully understood the definition of tolerance, but the teaching-learning process in the classroom lives an atmosphere of tolerance. The children have not fully understood the definition and concepts of peace, but the school culture familiarizes the value of peace. Direct experience is what ultimately shapes the children's identity so that their behaviour will always base on the values they believe.

The concept of values-based education is important to remember that in fact every child born into this world already has the capital value of goodness in them. The child just needs a real example. Therefore, anyone who interacts with students in school should reflect as role-models for values-based actions. 


\section{B. Values-Based on Environmental Education}

Like plant seeds, a good seed will grow well when planted in a fertile soil, enough nutritional intake, and water. Good seeds will not grow well when the soil has not enough food and water needed. It is similar to the seeds of values owned by every child. The seeds of good values must be supported by a values-based environment.

Children's values will develop when supported by ethos, culture, and positive school climate. Schools that have culture of mutual respect, tolerance, cooperation, and care will make the seeds of student's values to thrive. Conversely, school culture which is full of threats, intimidation, and fear will cause the children's potential to be undeveloped. Reference [16] describes a value-based environment as in figure 1.

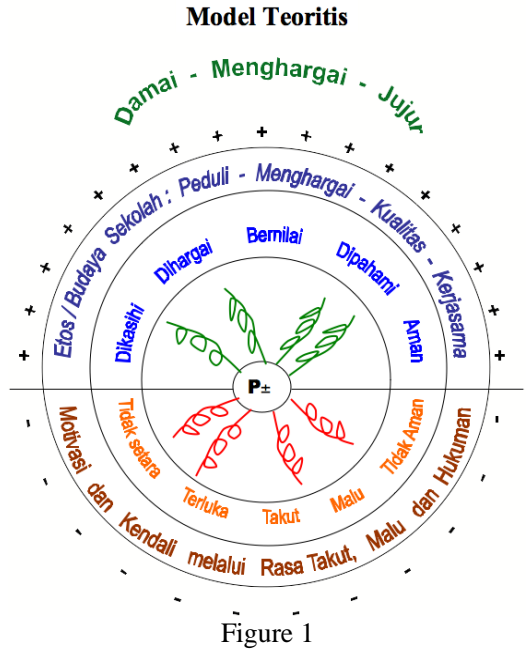

Figure 1 explains that the symbol $\mathrm{P}$ represents a child born in a condition of potential goodness. The potential of good will grow when the environment supports it by care, appreciation, quality, and cooperation. While the environment that does not cause a sense of security will cause the potential to undeveloped.

Reference [17] reveals that, there are three basic assumptions that need to be considered in the education of values namely;

"First, universal values teach respect and honor to every human being. Learning to enjoy those values will strengthen the well-being of individuals and communities. Second, every student is really concerned about values and able to create and learn positively when given a chance. Third, students are struggling in an atmosphere of values in a positive, safe, respectful, and compassionate environment where students are supposed to be able to learn to make environmentally conscious choices. "

Creating a values-based atmosphere can help students learn and practice values. Educators are required to reflect on their values. Teachers must have the awareness and skills to provide support, recognition, active listening, positive encouragement, conflict resolution, and collaboration.
To internalize student inner values, it is not enough by simply listening to the teacher's lecture on values, but rather they must experience and make those values a part of themselves. In fact, students do not just feel, experience, and think about values, but they must have the social skills to apply the values to daily life. Later, they do not only bring values to their personal lives, but also to the wider society.

\section{CONCLUSION}

Based on the description of the previous sections, there are two conclusions in this paper. First, values development requires an approach that enables children to experience value events directly. This experience can be gained through an example of the behaviour shown by adults around the children. The incidence of delinquency and irregular acts perpetrated by adolescents is due to the fact that they do not have moral guidance in building their identity. Second, values education also requires the support of values based on environmental education. Either the physical or non-physical environment of the school should reflect the values. Both concepts can be built through the paradigm of value-based education, not values education. This concept can be combined to strategies that the formal curriculum has developed in schools.

\section{REFERENCES}

[1] Terry Lovat and Ron Toomey, (eds). "Values Education and Quality Teaching",Springer Science+ Business Media. 2009

[2] Lickona, T. "Educating for Character: How Our Schools Can Teach Respect And Responsibility". New York: Bantam Books. 1991

[3] Nesbitt, Arweck, E., E., \& Jackson, R. "Common Values For The Common In School? Usingtwo Values Education Programmes To Promote 'Spiritual And Moral Development' ". Journal of Moral Education. 2005.

[4] Holmes, K., \& Crossley, M. "Whose Knowledge, Whose Values? The Contribution of Local Knowledge To Education Policy Processes: A Case Study Of Research Development Initiatives In The Small State Of Saint Lucia". Compare. 2004.

[5] Prencipe, A., \& Helwig, C. C. "The Development of Reasoning about The Teaching of Values in School and Family Contexts". Child Development. 2002

[6] Taplin, M. "Can We, Should We, and Do We Integrate Values Education Into Adult Distanceeducation? Opinions of Stakeholders at the Open University of Hong Kong”. International Journal of Lifelong Education. 2002.

[7] Tatto, M. T., Arellano, L. A., Tapia, M., Varela, A. L. \& Rodriguez, M. "Examining Mexico"s Values Education in a Globally Dynamic Context". Journal of Moral Education. 2001.

[8] Green, A. "Education, Globalisation and The Nation". London: Macmillan. 1997.

[9] Winecoff, H.L. \& Bufford, C. "Toward Improvrd Instruction: A Curriculum Development Handbook for International Scholls”. AISA. 1985.

[10] Thio, A. "Sociology. A Brief Introduction”. Boston: Pearson. 2005

[11] Giddens, A. "Sociology”. Oxford: Polity Press. 1991.

[12] Halstead J \& Taylor M (eds). "Values In Education And Education In Values". London: Falmer Press. 1996.

[13] Susanto, Dirto Hadi et.al. "Introduction to Educational Science (Pengantar Ilmu Pendidikan)". Yogyakarta: Fakultas Ilmu Pendidikan Dan Institute Keguruan dan Ilmu Pendidikan, Yogyakarta. 1995. 
[14] Egan, K.,. "Dalam Values and Ethics and the Science and Technology Curriculum". UNESCO. 1991.

[15] Kementerian Pendidikan Nasional Direktorat Jenderal Manajemen Pendidikan Dasar Dan Menengah Direktorat Pembinaan Sekolah Menengah Pertama, 2010. Panduan Pendidikan Karakter Di Sekolah Menengah Pertama.
[16] Tillman, Diane. "Living Values Activities For Young Adults (Pendidikan Nilai Untuk Kaum Dewasa Muda)", Jakarta: Grasindo. 2004.

[17] Tillman, Diane dan Colomina, Pilar Quera terj. M. Ika Purwowigati. "Pendidikan Nilai: Program Pendidikan Living Values: an Educational Program”. Jakarta: PT Grasindo. 2004. 